\title{
Problems With the Existence of Organs of Small and Micro Business Limited Company After the Law Is Implemented Number 11 Year 2020 Concerning Creation of Work
}

\author{
OK Isnainul ${ }^{1}$, Sandri Tarigan ${ }^{2}$, Kartina Pakpahan $^{3}$, Elvira Fitriyani Pakpahan ${ }^{4}$ \\ \{okisnainul@unprimdn.ac.id ${ }^{1}$, sandritarigan@gmail.com ${ }^{2}$, kartinapakpahan@unprimdn.ac.id ${ }^{3}$, \\ elvirapakpahan@unprimdn.ac.id ${ }^{4}$ \} \\ Universitas Prima Indonesia ${ }^{1234}$
}

\begin{abstract}
Limited Company (LC) in everyday life is closely related to the business world. With the enactment of Law No. 11 of 2020 concerning Job Creation, there are new arrangements for the convenience of Micro and Small Enterprises (MSE), with the ease of doing business with the presence of a LC form that is by the type of MSE. The normative juridical method used in the research, with descriptive nature. The purpose of this study is to analyze the existence of LC Organs for MSEs after the Employment Copyright Act is enacted, the legal consequences of LC established by an individual, the influence of Law No. 40 of 2007 concerning LC. There, three organs are consisting of the GMS: the Board of Directors, and the Board of Commissioners, after the work creation law was passed with the presence of an individual company. There is a change in the words of the GMS, becoming a decision on the establishment of an individual LC which has the same power as the GMS. The establishment of a LC is carried out by a minimum of two people with a notarial deed, while in the Job Creation Law for the establishment of a company with the MSE criteria; it is established by an individual based on a statement of the establishment made in the Indonesian language without having to use a notarial deed. Before the enactment of the Job Creation Act, the minimum capital for establishing a LC was Rp. 50,000,000 (fifty million rupiahs). However, the enactment of the Job Creation Law resulted in no minimum capital for the establishment of a LC and the presence of an individual LC with the MSE criteria that could be established by an individual.
\end{abstract}

Keywords: Limited Company, Organ of Limited Company, Small and Micro Enterprises

\section{Introduction}

The presence of a Limited Company (LC) as a business entity to drive the wheels of the economy is common in everyday life. Activities in the business world (business) cannot be separated from LC as a legal entity. Doing business with LC as a business entity with small or large criteria is mostly done by business actors. LC is a form of business entity that is a legal entity to operate in the economy, which is very popular with business actors at this time [1]. On 20/10/2019, Indonesian President Joko Widodo delivered a speech on the formation of the Omnibus Law through the Draft Law (RUU). The bill facilitates the business climate in Indonesia. The form of the Job Creation Bill, is expected to bring about changes in the 
economy which can increase by about five point seven percent to six percent with the creation of the business world increased investment by investors, increased income, increased consumption, and productivity accompanied by increased income, purchases and sales by investors [2].

The bill was enacted by Law no. 11 of 2020 concerning Job Creation. There are arrangements for ease of doing business for MSMEs, empowerment, and protection of MSMEs. Ease of running a business in the Act with the presence of an LC-type business entity with MSE criteria. The use of these business entities is exempted for middle and upper investors. In connection with this, the Job Creation Law, precisely in Article 153A, regulates that those that meet the MSE criteria can be established by an individual. A LC with the type of MSE is called an individual LC because its establishment can be carried out by an individual. In the United Kingdom, the European Union, and several countries in Asia, there is this type of LC. An individual LC with the MSE criteria is established using a statement of establishment by the founder of the company only then registered for ratification through electronic media by the Minister of Law and Human Rights, in this case, the establishment of the LC does not require the involvement of a notary in its establishment [3]

LC Law No. 40 of 2007 requires three organs, namely the GMS and the board of directors, and the board of commissioners is in LC. The highest authority that is not given to other company organs with limitations in the Limited Liability Company Law or the articles of association belongs to the GMS. The commissioner of the LC is not authorized to represent the LC unless it is regulated in the LC Law or articles of association. The commissioners as supervisors in the LC and provide advice/input to the directors, so that the policies carried out by the directors are by the Law and the LC articles of association and do not intentionally harm shareholders and stakeholders.

The Board of Directors in LC as management and representing the company, in carrying out all types of business activities both inside and outside the court. It is a must for LC to have directors as the management of the company. Because LC as an artificial person, cannot carry out business activities if no director acts as a natural person [4] To carry out business activities, including those related to law, the company is carried out by its management, namely the board of directors. The Board of Directors and LC have a relationship that cannot be separated from each other. Therefore, the Board of Directors and LC have a fiduciary relationship. Fiduciary duty to the management (board of directors) protects shareholders and LC. The Board of Directors acts on behalf of the LC and the shareholders. Therefore, the LC and the shareholders depend on the Board of Directors in carrying out business activities and cannot protect themselves. To avoid misappropriation of assets owned by LC, then the board of directors is given a fiduciary duty [5].

From the description above, the author is interested in conducting research entitled "Problematics with the Existence of Micro and Small Business Limited Liability Company Organs after the enactment of Law Number 11 of 2020 concerning Job Creation".

\section{Research Methods}

The type of normative juridical research used is research with a study of documents, with secondary data sources including laws, theories in legal science, and arguments from experts in the field of law [6]. With the nature of descriptive research, namely research to describe the 
phenomenon that is happening [7]. Primary and secondary and tertiary legal materials used in this study.

\section{Results and Discussion}

\subsection{Legal Consequences for a LC Founded by an Individual}

The term LC, was formerly known as Naamloze Vennotschap (NV). NV was used in the business world in Indonesia for quite a long time before the word Limited Company came into existence. The word comes from France with the name SA (Societe Anonym) which means a company without a name, meaning the LCwithout using the name of one of the shareholders, in this case using a name based on business activities (Article 36 KUHD) [8]. To carry out business activities at LC, there is an LC organ, with the duties and functions of each LC organ that are not the same between each LC organ. GMS and the Board of Directors and the Board of Commissioners which are organs of LC [9]. However, after the presence of an individual LC that meets the MSE criteria and is established by an individual regulated in the Job Creation Law, the GMS does not run perfectly as in the previous LC Law, which is equated with the founder's decision which has the same power as the GMS.

The establishment of the Company based on the LC Law is contained in Articles 7 to 14, with conditions that must be met by two or more people as founders of the LC, by using a notarial deed and legalized by the Ministry of Law and Human Rights, with shares that must be taken by the founders of the LC. These conditions must have met so that the LC is legally valid as a legal entity. The defect or non-fulfillment of any of these conditions results in the invalidity of the establishment of the LC [10]. The legal requirements for the establishment of an LC in Indonesia are regulated in Law 40 of 2007 concerning LC, namely [11].the existence of a deed of establishment, ratification by the Ministry of Law and Human Rights, and registration.

The establishment of an LC with the type of Micro, Small, and Medium Enterprises is regulated in Law No. 20 of 2008 concerning MSMEs as well as the establishment of a UMK company. The regulation on the Job Creation Law states that; the establishment of an MSEtype company is not required to be established by two people (maybe one person) with the establishment carried out using a statement of the establishment made under the hand, and ratification electronically to the Ministry of Law and Human Rights and for a clearer procedure described in Government Regulation No. 8 of 2021. Looking these provisions, the establishment of an MSE company is not a capital partnership if it is founded by an individual, but a statement of will by someone (singular) [12].

\subsection{Effect of Law No. 40 of 2007 concerning Limited Companies after the Enactment of Law No. 11 of 2020 concerning Job Creation.}

After the enactment of the Job Creation Law, it influenced the LC Law, especially regarding the capital and presence of LC, which is a type of MSE that can be established by an individual, while some of the differences are explained as follows:: 
Table 1. type of MSE that can be established by an individual

\begin{tabular}{|c|c|c|}
\hline No. & $\begin{array}{c}\text { Law of the Republic of Indonesia } \\
\text { Number } 40 \text { of } 2007 \text { concerning Limited } \\
\text { Companies. }\end{array}$ & $\begin{array}{l}\text { Law of the Republic of Indonesia } \\
\text { Number } 11 \text { of } 2020 \text { concerning Job } \\
\text { Creation. }\end{array}$ \\
\hline 1. & $\begin{array}{l}\text { Article } 7 \text { paragraph (1) requires the Company } \\
\text { to be established by } 2 \text { (two) or more persons } \\
\text { with a notarial deed drawn up in the Indonesian } \\
\text { language. Paragraph (5) states that after the } \\
\text { Company has obtained legal entity status and } \\
\text { the shareholders become less than } 2 \text { (two) } \\
\text { persons, within a maximum period of } 6 \text { (six) } \\
\text { months as of the said condition, the relevant } \\
\text { shareholder is obliged to transfer part of his } \\
\text { shares. }\end{array}$ & $\begin{array}{l}\text { An individual company is established by one } \\
\text { person and only has one shareholder. It is } \\
\text { regulated in Article } 153 \text { A paragraph (1) of } \\
\text { the Limited Company Law states that: } \\
\text { Companies that meet the criteria for Micro } \\
\text { and Small Businesses can be established by } 1 \\
\text { (one) person. In this case, the establishment } \\
\text { of a limited liability company does not } \\
\text { require a notary deed, but it is sufficient only } \\
\text { with a statement of the establishment made } \\
\text { by the founder and ratification by the } \\
\text { Minister, in this case, the establishment of a } \\
\text { limited liability company at a lower cost. }\end{array}$ \\
\hline 2. & $\begin{array}{l}\text { Limited Company shareholders can be } \\
\text { individuals and legal entities. }\end{array}$ & $\begin{array}{l}\text { An individual who can establish and become } \\
\text { a shareholder of an individual company. }\end{array}$ \\
\hline 3. & Shareholders can be Indonesian and Foreign & $\begin{array}{l}\text { The Founder and Shareholders are only } \\
\text { Indonesian. In Article } 6 \text { paragraphs (1) and } \\
\text { (2) Government Regulation Number } 8 \text { of } \\
2021 \text { concerning Authorized Capital of } \\
\text { Companies and Registration of } \\
\text { Establishment, Amendment, and Dissolution } \\
\text { of Companies that Meet the Criteria for } \\
\text { Micro and Small Businesses }\end{array}$ \\
\hline 4. & $\begin{array}{l}\text { Types of companies: } \\
\text { 1. Closed Limited Company } \\
\text { 2. Public Limited Company } \\
\text { 3. Open Limited Company }\end{array}$ & $\begin{array}{l}\text { Individual companies can only be } \\
\text { established for Micro and Small Businesses. } \\
\text { Back to the provisions of Article 153A } \\
\text { paragraph (1) of the Limited Company Law, } \\
\text { and further regulated in PP no. 8/2021 in } \\
\text { article } 2 \text { paragraph (1), it has been explained } \\
\text { that individual companies can only be } \\
\text { established for Micro and Small Businesses. }\end{array}$ \\
\hline 5. & $\begin{array}{l}\text { The authorized capital of a Limited Liability } \\
\text { Company as stated in article } 32 \text { is at least IDR } \\
50,000,000.00 \text { (fifty million Rupiah), and } \\
\text { article } 33 \text { states that at least } 25 \% \text { (twenty-five } \\
\text { percent) of the authorized capital must be } \\
\text { issued and fully paid into the company's cash }\end{array}$ & $\begin{array}{l}\text { Based on Article } 3 \text { jo. Article } 4 \text { PP No. } \\
8 / 2021 \text { stipulates that companies (including } \\
\text { individual companies) are required to have } \\
\text { authorized capital, the amount of which is } \\
\text { determined based on the decision of the } \\
\text { founder of the individual company, and } 25 \% \\
\text { (twenty-five percent) of the total authorized } \\
\text { capital must be issued and fully paid up, but } \\
\text { there is no minimum required capital is also } \\
\text { for individual companies. }\end{array}$ \\
\hline 6. & $\begin{array}{l}\text { Annual GMS must be held at the latest six } \\
\text { months after the end of the financial year. In the } \\
\text { annual GMS, there must be an agreement in the } \\
\text { form of submission of all report documents by } \\
\text { the company. The purpose of holding the } \\
\text { annual GMS is to approve several annual } \\
\text { reports of a Limited Liability Company, which } \\
\text { include: Financial statements covering, changes }\end{array}$ & $\begin{array}{l}\text { Several provisions must be observed and } \\
\text { followed by the founder of an individual } \\
\text { company. The first is the obligation to } \\
\text { prepare and submit financial reports (Article } \\
10 \text { PP No. 8/2021). This financial report must } \\
\text { be reported to the Ministry of Law and } \\
\text { Human Rights no later than } 6 \text { (six) months } \\
\text { after the end of the current accounting period. }\end{array}$ \\
\hline
\end{tabular}




\begin{tabular}{|c|c|}
\hline $\begin{array}{l}\text { in capital, the balance sheet at the end of the } \\
\text { new financial year in comparison with the } \\
\text { previous financial year, activities of the } \\
\text { Company, implementation of environmental } \\
\text { and social responsibilities, duties supervision } \\
\text { that has been carried out by the Board of } \\
\text { Commissioners during the previous financial } \\
\text { year. Names of members of the Board of } \\
\text { Directors and Board of Commissioners, } \\
\text { Salaries and allowances for members of the } \\
\text { Board of Directors and Board of } \\
\text { Commissioners of the Company for the } \\
\text { new/past year. }\end{array}$ & $\begin{array}{l}\text { The financial report contains: } \\
\text { a. statement of financial position, } \\
\text { b. income statement and } \\
\text { c. notes to the current year's financial } \\
\text { statements. } \\
\text { If they do not submit financial reports, } \\
\text { the Individual Company may be subject to } \\
\text { sanctions, including: } \\
\text { a. written warning; } \\
\text { b. termination of access rights to services, or } \\
\text { c. revocation of legal entity status. } \\
\text { The second is the limit on how many } \\
\text { individual companies can be established by } \\
\text { the founder. Article } 153 \mathrm{E} \text { paragraph (2) of the } \\
\text { Limited Company Law stipulates that } \\
\text { founders can only establish } 1 \text { (one) company } \\
\text { for Micro and Small Businesses in } 1 \text { (one) } \\
\text { year. } \\
\text { The addition of Article } 153 \text { which is } \\
\text { divided into } 10 \text { Articles (153A, 153B, 153C, } \\
153 \mathrm{D}, 153 \mathrm{E}, 153 \mathrm{~F}, 153 \mathrm{G}, 153 \mathrm{H}, 153 \mathrm{I}, 153 \mathrm{~J} \text { ). }\end{array}$ \\
\hline
\end{tabular}

Based on the table above, it can be concluded that the Job Creation Law. It has an influence on the LC Law with changes to various articles $(1,7,32)$ and additions to article 153, which is divided into ten articles that present an Individual LC that meets the MSE criteria that can be established by an individual. without any capital alliance from other parties to facilitate its establishment, in which case the establishment of individual LC is sufficient with a statement of the founder made under the hand without having to use a Notary deed as regulated in the Company Law before the enactment of the Job Creation Act.

\section{Conclusion}

The organs of LC, namely the GMS, the Board of Directors, and the Board of Commissioners, after the enactment of the Job Creation Law and the presence of LC by fulfilling the MSME Criteria established by an individual, there is a change in the words of the GMS, becoming a Decision of the Founding of an Individual Company which has the same power as the GMS. Establishment of a Limited Company based on the Limited Company Law requires more than one founder using a notary deed, while after the enactment of the Employment Copyright Law it states that the establishment of a company with the MSE criteria can be established by an individual, it is enough with a statement of establishment made under the hand and in Indonesian without using a notary deed.

The enactment of the Job Creation Law cannot be separated from the Limited Liability Company Law, for the establishment of a PT must have a minimum capital of Rp. 50,000,000, - (fifty million rupiah) after the enactment of the Job Creation Law, it no longer requires a minimum capital in the establishment of a PT and the presence of an Individual PT that meets the UMK criteria it is possible to establish an Individual PT individually, without having to have a capital partnership, and it is an additional Article 153 which is divided into 10 Articles (153A to $153 \mathrm{~J})$. 


\section{References}

[1] Bambang Waluyo, Penelitian Hukum Dalam Praktik, Jakarta, Sinar Grafika, 1996.

[2] Binoto Nadapdap, Hukum Perseroan Terbatas berdasarkan Undang-Undang Nomor. 40 Tahun 2007, Jala Permata Aksara, Jakarta.2020.

[3] M. Yahya Harahap, Hukum PT, Sinar Grafika, Cet. Ke VII, Jakarta, 2019.

[4] I.G. Rai Widjaya, Hukum Perusahaan PT, Edisi Revisi, Cetakan Ke 6, Jakarta, Kesain Blanc, 2006.

[5] P. M. Marzuki, Penelitian Hukum, Jakarta, Prenada Media, 2005.

[6] R. Prasetya, PT Teori dan Praktik, Jakarta, Sinar Grafika, 2011.

[7] Ahmad yani dan Gunawan Widjaja, Seri Hukum Bisnis, Perseroan Terbatas, Edisi 1, Cetakan 3, PT Grafindo Persada, jakarta, 2003, hlm. 77.

[8] Y. W. Hardiyono, Dkk, Keabsahan dan akibat hukum pendirian perseroan mikro dan kecil berdasarkan UU Cipta Kerja, Jurnal ilmiah ilmu hukum, vol. 27, no 8, hlm. 1094 